\title{
Strategy of Literacy and Art Education in Creating Critical Thinking in West Sumatra
}

\author{
Rika Febriani \\ \{febriani.febriani@gmail.com\} \\ Department of Philosophy, Sekolah Tinggi Filsafat Driyarkara, Jakarta, Indonesia
}

\begin{abstract}
The problem of uncritical thinking in society when receiving information in the digital age is now worrying. The mass circulating information flow has created a separate reality from the real world. The negative impacts of less critical of society can be seen from various things, such as: the spread of fear and terror, deceived by the piety, and the insensitivity of a group to people towards different views from theirs. To create a critical society needs to begin by incorporating the teaching of sharpening emotions and reasoning power through literary and art. Teaching quality literary works can give people the space to reflect, enrich the perspective of different people without changing their identity. How far is the role of literature and art in creating critical society? What would be the impact if implemented into a homogeneous community group such as in West Sumatra? The presumption that local traditions are true has proven to inhibit tolerant attitudes within the community at the local level. This is qualitative research by using the argument from Martha C. Nussbaum who sees that emotion is very important in giving moral decisions which contained in the expression of citizen's choice. The use of critical thinking should be trained in a structured education.
\end{abstract}

Keywords: art, literature, emotion, education, rationality, tolerance, pluralism.

\section{Introduction}

The spreading of hated speech increases in Indonesia. One of the incidents that became the "alarm" against the hate speech occurred at the Election of Regional Head (Pilkada) DKI Jakarta in 2017. The incumbent governor, Basuki Tjahaja Purnama or known as Ahok became the target of religious politicization amplified through social media. The combination between the uncritical community in responding towards religious issues and the high use of social media resulted in increased intolerance in Indonesia. This hate speech can easily be found in the form of posters with text, photos, memes and videos within social media. It is dangerous because it not only ceases to be a discourse in social media but then develops into persecution in the real world.

At the State level, some indicators of intolerance can be seen based on Medium Term Local Development Plan (RPJMD), local regulations, concrete actions of the local government in responding to religious freedom in its territory, violations of religious freedom and religion's demographic. Based on these indicators, Padang becomes the city with the lowest tolerance score in Indonesia; the position is under Makassar and above Mataram [1]. Padang and West Sumatera generally have characteristics of the homogenous population, besides the ethnic majority of Minangkabau, in West Sumatera, the majority religion is Islam (98\%), Christian $(1,6 \%)$ and others $(0,4 \%)$. Homogeneity based on the religion has made the people of West 
Sumatra tend to be resistant to people of different believes with them. The customs and cultures that are in line with the views of the Minangkabau people's lives based on "philosophy", "adat bersandi syarak, syarak bersendi kitabullah" become the best claims merging between customs, traditions and religions. As a moral value, this local philosophy is the best thing. However, when it comes to relations towards other, it must best be suspicious because it tends to marginalize minority groups and insensitivity towards different people, the other forms can be seen from the strong resistance from the community and easily fascinated by piety.

An interdisciplinary approach is needed to reduce intolerance in West Sumatra. In this case, cultural studies that underlined the diversity is very relevant in society. Understanding people who are different from us is very important because the world is getting smaller with globalization and interdependence towards a human being. Diversity is a necessity and an unavoidable thing in life. Cultural studies can provide theoretical tools for analyzing power relationships where conditions of production, circulation and dissemination and of course cultural impact [2]. The teaching of cultural criticism must be done systematically, starting from basic education. Citizenship education has first provided this foundation, but citizenship education alone is not sufficient although teaching students about culture and its complexity while trying to provide conceptual understanding where they can implement it is a messy thing [3].

The ability to understand different people is often associated with humanity and art. In this connection the ability to think critically and transcend devotion to the religion adopted and the ability to imagine others sympathetically. The education of religious tolerance comes from the concept of multiculturalism as a recognition of the rights and freedoms of social groups [4]. However, in a homogeneous society, students have a limit in experience knowing other cultures and religions. Sometimes resistance to the value of multiculturalism is carried out by conservative groups [5].

\section{Research Method}

This research used qualitative methodology by analyzing how literary and art education can help the student to imagine different people within a homogeneous group in order to create tolerance in society. The analysis of the importance of the concept of literary and art education comes from Martha C. Nussbaum, the contemporary American philosopher. Nussbaum explains the importance of critical thinking to create a cosmopolitan society. Systematic education is useful for developing student capabilities. The concept of human being as the ultimate capability is based on the idea that humans from different socio-cultural backgrounds can share a common concept of society. This raises optimism so that we can have a theory that not only a projection of local preferences but becomes an international basis for cross-cultural adjustment.

The author limits to the elaboration of the idea between the importance of literary and arts education as an alternative solution towards intolerance in homogenous society like in West Sumatra. In this case, authors see that this kind of education can serve the purpose of each person so that in the wider scope can create social justice in Indonesia. 


\section{Literacy and Critical Thinking in Society}

The process of critical thinking in formal education can be done by reading literary works and how the students can interpreting the art. Critical education by using literary works or known as critical literacy is an ability based on high-level understanding and interpretation of complex issues in the literature by introducing social, political and ideological dimensions with emphasis on important issues [6].

This critical literary work demonstrating cultural diversity through the understanding of ideological foundations towards marginalized knowledge, culture, education in schools, groups, and identity-making is something politically unavoidable, characterized by personal interests and hidden agendas [7]. Through the lens of critical literary works is expected to reveal the social function of the text in placing individuals and groups of people.

Literary works cannot transform society in unity, but it is trying to see the differences within society so that local traditions and cultures can see other than their values. Meanwhile, artwork can make the audience recognize "the invisible" group, and this can be the beginning for the idea of social justice [8].

There are four dimensions in critical literary works related to cultural diversity: first, a critical point of view can challenge conventional assumptions and stereotypes; second, it is possible to understand different perspectives; third, focus on social and political issues; fourth, take action and promote social justice [9]. Art and literature can build capacity for perceptions and decision-making, including understanding the aspirations and complexities of the world rather than seeing society as numbers and statistics.

Citizenship education in Indonesia has been trying to develop the attitude of understanding different groups through Pancasila. However, Pancasila education alone is not sufficient to create a tolerant society. It is important to place literary and artistic works within the educational curriculum whose functions have relations with civic education. It is important because it can build the art of interpretation in order to create civil society participation and awareness within the nation.

In Minangkabau, various classical literary works provide an overview of the governance of society and the role of women since ancient times. Three well-known classic literary works include: Kaba Tjindua Mato, Kaba Sabai Nan Aluih, Kaba Rantjak Dilabuah are three stories that illustrate the critical role of women in Minangkabau [10]. There are many other literary works can be used as literary and art education materials in West Sumatera but have not yet studied its role seriously in shaping the imagination of diversity. There aren't so many people who try to reinterpret the literary work. The reinterpretation of literary works seems very taboo. The important role of literature and art is to challenge conventional values and wisdom. As Nussbaum predicted, resistance or feelings of the offense must be faced by conventional people, but the offense of a work of art is part of the value of citizenship [8]. If a work of literature and art can touch human life, then he can provide judgment, interpretation, and appreciation. Nussbaum sees that the imagination of literary works can create a feeling of emotion that can be useful for public responsibility. The types of works that can articulate the experiences of groups within society important to understand and create mutual respect.

We also realized that the text of literary works could be non-neutral to the existing reality, but rather the social construction of artifacts representing the subject matter while silencing others and influencing the ideas of society [11]. Literary works are also not free from the prejudices and weaknesses that always exist in political life. We can also criticize the literary and artistic literature by feeling something that is wrong with the work. At this stage, sympathetic and critical readings can proceed simultaneously, as we ask how sympathetic 
feelings can be shared and focused. A person can be critical if they can see the internal structure with new exposure and make the relationship appropriately.

This evaluative approach to the reading of literary and artistic works can be both moral and political. They can ask how readers and texts can form relations with the community and invite us to discuss texts with moral and social judgments. So it is also important to protect the rights of teachers in exploring contemporary and literary works of art apart from what they believe.

\section{Critical literacy and arts education in creating tolerance in the homogenous society}

As part of post-Indonesia democratization and decentralization, there are important changes in the education system [12], [13]. The current Indonesian curriculum focuses on achieving competence rather than teach pedagogical aspects that should center on students who focus on active learning [14]. The curriculum in Indonesia says that students should be able to think critically, rationally respond to the issue of citizenship. This concept was applied in civic education in 2002 in Indonesia based on the values of Pancasila. The research saw that formal schools affected inter-ethnic and interreligious socialization in five provinces in Indonesia, including West Sumatra. The factor that influences the behavior of interfaith and ethnic relations are: ethnicity, type of school and community. In West Sumatra, which consists of a majority of Minang tribes and Muslims, it provides little opportunity for students to know people who are different from them. This homogeneity is more on environmental factors that make it difficult for students to recognize people with different cultural backgrounds than theirs.

For Minangkabau society, adat is related to morals, whereby the idea is crystallized in a universal system [10]. Although custom is a manifestation of Islam, Minangkabau society does not explore the meaning of this relationship in depth. Both adat and Islam are a unity of concepts, moral teachings and embodied in everyday life. However, in order to be able to advance in the real the world, it certainly takes more than this "philosophy" [14]

In the midst of information flows from social media in Indonesia, the students should have the opportunity to know different cultures and religions through the internet. However, along with the sophistication of algorithms based on the word search, students and the general public tend to find the ones who share their ideas. Adding the problem by increasing the number of human attention span, students become lazy to browse the existing news so that the reading of literary works can train the ability of reflection and attention of students.

Studying literature and art does not require an environmental change that is already given in the community. Humans can not choose what traditions and values they are born and raised. Therefore, through literary and artistic works hopefully can open insight and critical to the local culture of students who are live in a homogeneous environment such as in West Sumatra.

\section{Conclusion}

West Sumatra is a province with homogeneous ethnicity and religions. The long history of the Minangkabau and Islamic religions makes the customs and culture very strong in this province. The challenges that occur today are more people less sensitive to people that differ from them, religiously, ethnically and ideologically. This strong attitude is increasingly worrisome for the life of the nation because diversity is a necessity. Education that is sharpening 
the emotions such as critical literacy and art is needed. This teaching should be done systematically in a formal school and not just as an additional lesson as it is today. Literary and artistic works are expected to provide a sense of empathy without having to have direct experience with different groups.

\section{References}

[1] SETARA Insitute dan Unit Kerja Presiden-Pembinaan Ideologi Pancasila,. Indeks Kota Toleran Tahun 2017, http://setara-institute.org/indeks-kota-toleran-tahun-2017/

[2] Bennett, T. (1998). Culture: A reformer's science. Sydney

[3] McRobbie, A. (1992). Post-Marxism and cultural studies. In L.Grossberg, C. Nelson, \& P. Treichler (Eds.), Cultural Studies, (pp. 719-730). New York, NY: Routledge.

[4] Mirchandani, K, \& Tastsoglou, E. (2000). Towards a Diversity Beyond Tolerance. Studies in Political Economy.

[5] Kauff, Mathias et al. (2013). Side Effects of Multiculturalism. Personality and Social Psychology Bulletin.

[6] Cervetti, G., Pardales, M.J., \& Damico, J.S. (2001). A tale of differences: Comparing the traditions, perspectives, and educational goals of critical reading and critical literacy. Reading Online, 4(9). Retrieved September 28, 2009, from www.readingonline. org/articles/art_index.asp?HREF=cervetti/index .html

[7] Kelly, U.A. (1997). Schooling desire: Literacy, cultural politics, and pedagogy. New York: Routledge

[8] Nussbaum, Martha C. (1997) Cultivating Humanity: A Classical Defense of Reform in Liberal Education, Harvard University Press Lewison, M., Flint, A. S., Van Sluys, K. (2002). Taking on critical literacy: The journey of newcomers and novices. Language Arts, 79, 382-392.

[9] Abdullah, Taufik. "Some Notes on the Kaba Tjindua Mato: An Example of Minangkabau Traditional Literature", Indonesia, No. 9 (Apr., 1970), pp. 1-22

[10] Luke, A., \& Freebody, P. (1999, August). Further notes on the four resources model. Reading Online. Retrieved September 28, 2009, from www.readingonline.org/past/past_index .aspPHREF^research/lukefreebody.html

[11] Kristiansen, S., \& Pratikno. (2006). Decentralizing education in Indonesia. International Journal of Education Development, 26(5), 513-531

[12] Raihani. (2007). Education reform in Indonesia in the twenty-first century. . International Education Journal, 8(1), 172-183

[13] Parker, Lyn, \& Chang-Yau Hoon, Special Issue: Education For a Tolerant and Multicultural Indonesia: Introduction, South East Asia Research, Vol. 22, No. 4 (December 2014), pp. 459465

[14] Simon, Gregory M. (2014). "Being Minangkabau: Imagining Adat, Islam, and Ethnic Character", Caged in on the Outside, University of Hawai'i Press. 